\title{
THE USAGE OF BAGASSE PULP FOR WOOD FIBER SUBSTITUTION IN PAPERMAKING
}

\author{
Darono Wikanaji ${ }^{\text {* }}$, Trismawati $^{\mathrm{b} * *}$, Pepi Kartiko ${ }^{\mathrm{c}}$ \\ a,b Panca Marga University, Jl. Yos Sudarso 107 Pabean Dringu, Probolinggo 67271, Indonesia \\ *aji_darono@yahoo.co.id,**trisma.saja@yahoo.co.id \\ 'PT Kertas Leces (Persero), Jl Raya Leces - Probolinggo, Indonesia; pepi.kartiko@gmail.com
}

Diterima : 6 September 2012, Revisi akhir : 27 Desember 2012

\section{PENGGUNAAN PULP BAGAS UNTUK SUBSTITUSI SERAT KAYU PADA PROSES PEMBUATAN KERTAS}

\begin{abstract}
ABSTRAK
Penelitian pulp bagas virgin dan bagas pasaran sebagai bahan baku pembuatan kertas tisu gramatur $17 \mathrm{~g} / \mathrm{m}^{2}$, kertas HVS $56 \mathrm{~g} / \mathrm{m}^{2}$, dan karton BC $210 \mathrm{~g} / \mathrm{m}^{2}$ dalam rangka substitusi serat LBKP dan NBKP telah dilakukan. Kertas tisu MG yang dibuat di PM4 pada kecepatan 3,2 \% lebih rendah dan 6,7\% kapasitas lebih rendah ternyata mampu mensubstitusi seluruh porsi LBKP $(60 \%)$ tanpa efek negatif pada sifat fisik kertas. Kertas HVS dibuat di PM5 pada kecepatan 4,3\% lebih rendah dan kapasitas 1 $\%$ lebih rendah ternyata mampu meningkatkan indeks kekuatan, indeks tarik, dan indeks sobek, serta mengurangi porositas hingga $800 \mathrm{ml} / \mathrm{mnt}$. Karton BC dibuat di PM2 pada kecepatan dan kapasitas yang sama ternyata mampu mensubstitusi porsi LBKP $(40-80 \%)$ dan NBKP $(10-20 \%)$ tanpa pengaruh negatif pada sifat fisik. Tetapi sifat BC masih berada diantara batas bawah dan batas atas BC komersial, meskipun ada penurunan tajam pada indeks kekuatan dan ketahanan lipat dibandingkan dengan $\mathrm{BC}$ yang menggunakan $20-30 \%$ NBKP.
\end{abstract}

Kata kunci : pulp bagas, indeks tarik, indeks kekuatan, indeks sobek, porositas

\section{ABSTRACT}

Research of virgin bagasse pulp and market bagasse pulp as the furnish for MG tissue $17 \mathrm{gsm}$, HVS paper $56 \mathrm{gsm}$, and BC paper $210 \mathrm{gsm}$ has been done for NBKP and LBKP substitution. MG tissue was produced on $\mathrm{PM} 4^{\text {th }}$ at $3,2 \%$ lower speed and $6,7 \%$ lower throughput is able to replace the whole LBKP portion $( \pm 60 \%)$ with no negative effect on physical properties at all. The use of bagasse pulp up to $15 \%$ to substitute LBKP in the furnish of HVS produced on PM $5^{\text {th }}$ at $4,3 \%$ lower speed and $1 \%$ higher throughput is able to improve strength index, tensile index, and tear index, and reduces the porosity up to $800 \mathrm{ml} /$ minute. Bagasse pulp for BC paper was produced on PM $2^{\text {nd. }}$ at the same speed and throughput is able to replace some portion of LBKP $(40-80 \%)$ and NBKP $(10-20 \%)$ with apparently no negative effect on physical properties. But, properties of BC still on between the high and low level properties of $\mathrm{BC}$ available on the market, even though a sharp decrease of strength index, tear index and double fold has been found when compared to BC 210 gsm using 20 - 30\% NBKP.

Keywords: bagasse pulp, tensile index, strength index, tear index, porosity

\section{INTRODUCTION}

Wood demand for pulp and paper industries has increase significantly since some decades ago. This everlasting condition seems goes increase further in the incoming years. The Indonesian annual installed pulp production capacity has grew up significantly from 1 million tons in 1990 to nearly 6.5 million tons in 2009 and it is estimated will up to around 7 million tons in 2015 (Poyry Consulting, 2012). This mean the wood resources needed will be around 34.6 million $\mathrm{m}^{3}$ of round woods or around 25 ton of round wood for the year 2012. On the other hand the forest 
degradation goes up continuously with the rate of degradation around minus $2 \%$ per year in Asian countries especially in Indonesia. These were happened because of the conversion of forest to non-forest, forest to plantation, and decrease of forest canopy hardly controllable continuously happened and the HTI allocated area for sawn wood, pulp and paper, and even HTI Trans not yet planted effectively except for HTI Pulp at Jambi. The rapid expansion of pulp and paper industries in Indonesia has underlying the development of HTI concessions but does not effectively manage yet (Emily Matthews, 2002).

What had been done by PT Kertas Leces (Persero) as a trendsetter in using bagasse pulp as one constituent on its raw material in producing its products since more than 30 years ago and rice straw pulp since more than 80 years ago were mentioned even though this everlasting product should be ended in the mid of 1990's because of economic and policy situation, but the effort back to bagasse pulp for its raw material or other nonwood pulp for specialty product is everlasting.
Using bagasse pulp as the only raw material will not be able to produce a good quality of paper but acceptable quality still possible. On the other hand using bagasse pulp as the main constituent with other wood pulp as the balance of the raw material will be able to get a good quality and some special quality of properties of product.

\section{Literature Review}

The raw material of bagasse pulp and wood pulp (hardwood pulp and softwood pulp) has very different properties. The physical and chemical characteristic is quite different.

\section{Raw Material Properties}

The quite wide range properties of bagasse and so does hardwood and softwood will give effect on the physical properties of the pulp produced. Increasing tree age, the amount of cellulose, extractives and lignin are increases but the amount of hemicelluloses and ash decreases (Kasmani et al, 2011)

Table 1.Chemicals Properties Several Raw Material

\begin{tabular}{ccccc}
\hline Compound & Bagasse, $\%$ & $\begin{array}{c}\text { Eucalyptus camaldulensis } \\
(6-10 \text { years old })^{4}, \%\end{array}$ & $\begin{array}{c}\text { Acacia mangium, } \\
(7 \text { year old }), \%\end{array}$ & Spruce and Pine, $\%$ \\
\hline Cellulose & $42-45$ & $38-46$ & $45-48$ & $39,5-40$ \\
Hemicellulose & $28-33$ & $16-27$ & $28-30$ & $28,5-30,4$ \\
Lignin & $17-22$ & $18-24$ & $23-24$ & $27,5-27,7$ \\
Extraction & $2-3$ & $2-5$ & $3-4$ & $2,1-3,5$ \\
Ash & $1.1-2.1$ & $0.43-076$ & $\mathrm{Na}$ & na \\
\hline
\end{tabular}

Table 2. Physical Properties of Bagasse Pulp, LBKP (Acacia and Euca), and NBKP (Spurce Softwood Pulp)

\begin{tabular}{lccccc}
\hline \multicolumn{1}{c}{ Properties } & Acacia Pulp & Euca. c. Pulp & $\begin{array}{c}\text { Bagasse Pulp } \\
\text { EPCO }\end{array}$ & $\begin{array}{c}\text { Bagasse Pulp under } \\
\text { studied }\end{array}$ & Spurce Pulp \\
\hline Freeness, CSF / SR & $400 / 32$ & $400 / 32$ & $400 / 32$ & $400 / 32$ & $400 / 32$ \\
Brightness (\% ISO) & $>88,5$ & 89,5 & 79,3 & 80 & 89,75 \\
Bulk (cm3/g) & 1,41 & 1,29 & 1,24 & 1,33 & 1,24 \\
Tensile (N.m/g) & 62,22 & 44,75 & 41,57 & 37,95 & 87,8 \\
Tear (mN.m2/g) & 7,97 & 10,0 & 6,86 & 3,70 & 10,1 \\
Burst (kPa.m2/g) & 5,67 & 5,07 & 3,87 & Na & 6,01 \\
\hline
\end{tabular}


Table 3. Quality of Paper Product Use Bagasse Pulp

\begin{tabular}{lccc}
\hline \multicolumn{3}{c}{ Bagasse Pulp and Long Fiber Virgin Woodpulp } & Quality \\
\hline Type of Paper & \multicolumn{1}{c}{ Bagasse (\%) } & Long Fiber Pulp (\%) & Excellent \\
Corrugating medium & 90 & 10 & Good \\
Lightweight MG wrapping (1) & $65-75$ & $25-35$ & Acceptable \\
Sanitary tissue \& towelling & $60-70$ & $30-40$ & very good \\
Test liner (2) & $80-85$ & $15-20$ & Good \\
Wood-content writing papers & $75-85$ & $15-25$ & very good \\
Woodfree writing papers & $80-90$ & $10-20$ & very good \\
\hline
\end{tabular}

Notes [3]:

(1) Bleached or unbleached.

(2) Select kraft wastepaper could substitute a portion of the long fiber virgin woodpulp.

(5) Bleached chemimechanical or high-yield chemical pulp used for part of bagasse furnish.

Table 4. BC 210 GSM Quality Properties Available on The Market

\begin{tabular}{ccccccccc}
\hline $\begin{array}{c}\text { Market } \\
\text { Position }\end{array}$ & $\begin{array}{c}\text { Strength } \\
\text { Index, } \mathrm{km}\end{array}$ & $\begin{array}{c}\text { Int. } \\
\text { Bond, } \\
\mathrm{J} / \mathrm{m}^{2}\end{array}$ & $\begin{array}{c}\text { Tear } \\
\text { Index, } \\
\mathrm{mNm}^{2} / \mathrm{g}\end{array}$ & $\begin{array}{c}\text { Burst } \\
\text { Index, } \mathrm{kPa} \\
\mathrm{m}^{2} / \mathrm{g}\end{array}$ & $\begin{array}{c}\text { Ring } \\
\text { Crush } \\
\mathrm{N}\end{array}$ & $\begin{array}{c}\text { Tensile } \\
\text { Index, } \\
\mathrm{Nm} / \mathrm{g}\end{array}$ & $\begin{array}{c}\text { Double } \\
\text { Fold, x }\end{array}$ & $\begin{array}{c}\text { Wax Pick, } \\
\text { DN No }\end{array}$ \\
\hline HV std & 310 & 235 & 7,25 & 3,1 & 312 & 67,3 & 188 & 20 \\
LV std & 238 & 184 & 5,61 & 1,7 & 294 & 40,7 & 36 & 16 \\
\hline
\end{tabular}

\section{Pulp Properties}

The physical properties of non wood pulp, hardwood pulp and softwood pulp are also quite deference. Below are some of them on Table 2.

\section{Paper Quality}

Many researches had been done in producing some quality of paper product. Some of them are listed on the Table 3 .

\section{Experimental / Operational}

The raw material used is the existing pulp normally used at PT Kertas Leces (Persero). The composition variation was suited for every product under examination. The product under examination was categorized under tissue paper, industrial paper, and writing printing paper. The evaluated composition for every category of paper is suited for the recommended paper quality of product and paper machine run ability that should be maintained. Other operational variable except furnish composition kept constant in every experiment. In case of any process disturbances as a result of furnish drain ability the only allowable adjustment is speed reduction in order to maintain the paper machine run ability to keep the constant throughput. The result was compared to any product quality on the market with the properties as follows (Table 4).

\section{RESULT AND DISCUSSION}

In case of MG tissue paper category, the examined product was MG tissue $17 \mathrm{gsm}$ with $45 \%$ NBKP and $50 \%$ LBKP, and 5\% Recycle fiber as the original composition. Previously, paper machine speed was $627 \mathrm{mpm}$ with average total throughput 30 ton/day. The adjusted furnish composition under examination was bagasse pulp $60 \pm 5 \%$ to substitute all LBKP portion, recover fiber 5\%, and the rest was NBKP as a balance to reach $100 \%$ composition. In this case the NBKP portion was only $35 \%$ as an alternative of $45 \%$ previously. The adjusted speed was $607 \mathrm{mpm}$ with average total throughput was 28 ton/day (3,2\% lower speed and 6,7\% lower throughput). It seems that wet sheet drain-ability was the major drawback that had forced the machine attendance to decrease the machine speed. The results are 


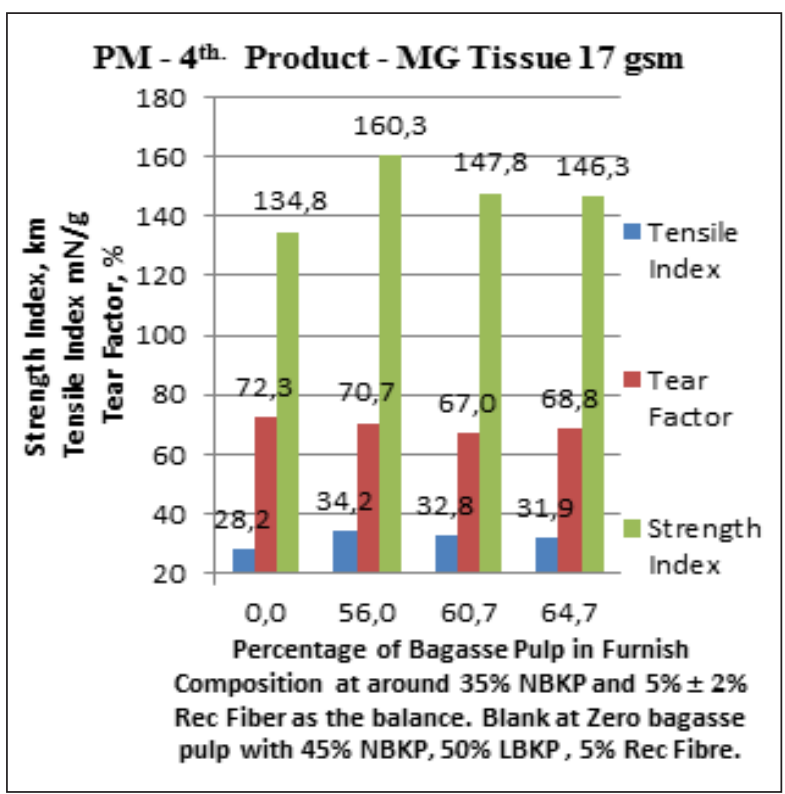

Figure 1. Effect of Bagasse Pulp on MG Tissue Properties

as follows (figure 1 and figure 2). From figure 1 and figure 2, it can be concluded that bagasse pulp might substitute some portion of LBKP and reduce the amount of NBKP for at least $10 \%$. The original composition (blank) was bagasse pulp $0 \%$, NBKP $45 \%$, LBKP $50 \%$ and recovered fiber $5 \%$. The examined composition variation was bagasse pulp 56\%, 61\%, 65\%, NBKP around $35 \%$, and recovered fiber $\pm 5 \%$ as the balance. The MG tissue $17 \mathrm{gsm}$ properties achieved is quite resembles with tensile index, strength index, breaking length, and gloss is higher when using bagasse pulp to substitute some portion of LBKP and NBKP, but the tear factor and tear index is a little bit lower.

In case of writing and printing paper category that was produced at PM $5^{\text {th }}$, the examined product was HVS 56 gsm with $70 \%$ LBKP and $30 \%$ broke fiber as the normal composition. The original paper machine speed was $578 \mathrm{mpm}$ with average total throughput 187 ton/day. The adjusted furnish composition under examination wass LBKP $\pm 60 \%$, bagasse pulp $\pm 10 \%$, NBKP $0 \%$, recovered fiber $30 \%$ to reach $100 \%$ composition. The adjusted speed was $556 \mathrm{mpm}$ with average total throughput was 190 ton/day (3,8\% lower speed but $1,6 \%$ higher throughput). The result is as follows (figure 3 and figure 4) In this case seems that again the same drawback had happened again such as in the MG tissue production at PM $4^{\text {th }}$, wet sheet drain-ability had force the machine attendance to reduced the

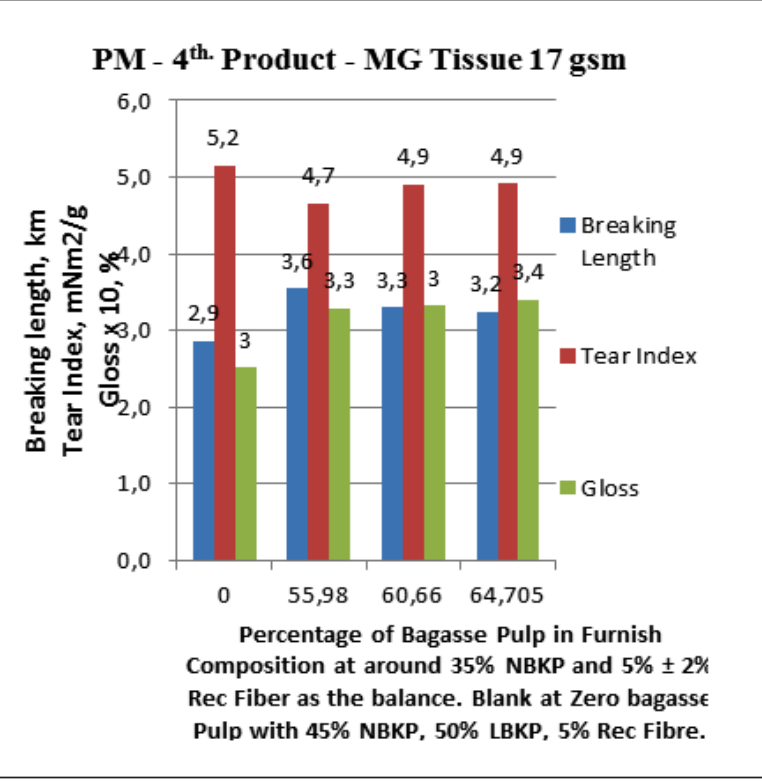

Figure 2. Effect of Bagasse Pulp on MG Tissue Properties

machine speed, but fortunately the throughput could be kept constant and even a little bit higher.

From figure 3 and figure 4, it can be concluded that bagasse pulp might substitute some portion of LBKP. The original composition (blank) is bagasse pulp $0 \%$, NBKP $0 \%$, LBKP $70 \%$ and recovered fiber $30 \%$. The examined composition was variation of bagasse pulp $7 \%, 9 \%, 15 \%$, recovered fiber $28-30 \%$ and LBKP as balance to reach $100 \%$ furnish composition. The HVS $56 \mathrm{gsm}$ properties achieved is quite resembles with tensile index, strength index, tear factor, tear index, breaking length are higher when using bagasse pulp to substitute some portion of LBKP, but the porosity is lower than before as the prerequisite of this base paper.

In case of industrial paper category, the examined product was BC Paper 210 gsm, The original composition (blank) was bagasse pulp $0 \%$, NBKP $10-15 \%$, LBKP $70-80 \%$ and recovered fibre $10 \%$. The paper machine speed kept constant and $150 \mathrm{mpm}$ and average total throughput 70 ton/day. The adjusted furnish composition under examination were such follows: (i) LBKP \pm $15,35,45,55,75 \%$, bagasse pulp $\pm 20,40,50$, $60,80 \%$ and recovered fibre $5 \%$ to reach $100 \%$ composition with zero NBKP as the first trial and (ii). NBKP 10, 15, 20, 30\%, LBKP $=60,70,75$, $80 \%$, and recovered fibre $10 \%$ to reach $100 \%$ composition with zero bagasse pulp as the second trial. The results is presented on (figure $5 \mathrm{a}, \mathrm{b}$ until figure $8 a, b)$. Figure $5 a-6 a$. Effect of bagasse 


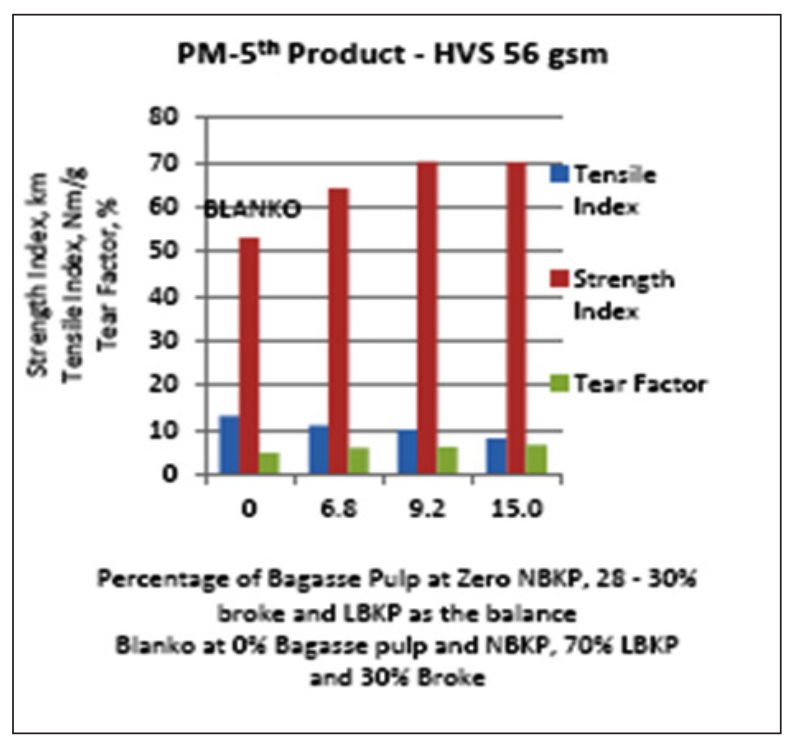

Figure 3. Effect of Bagasse Pulp on HVS 56 gsm

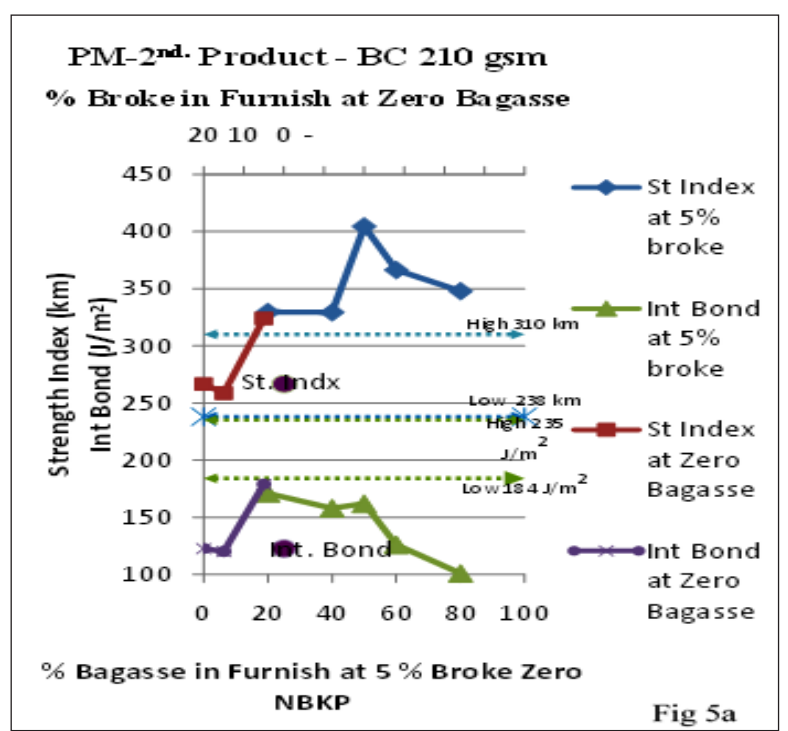

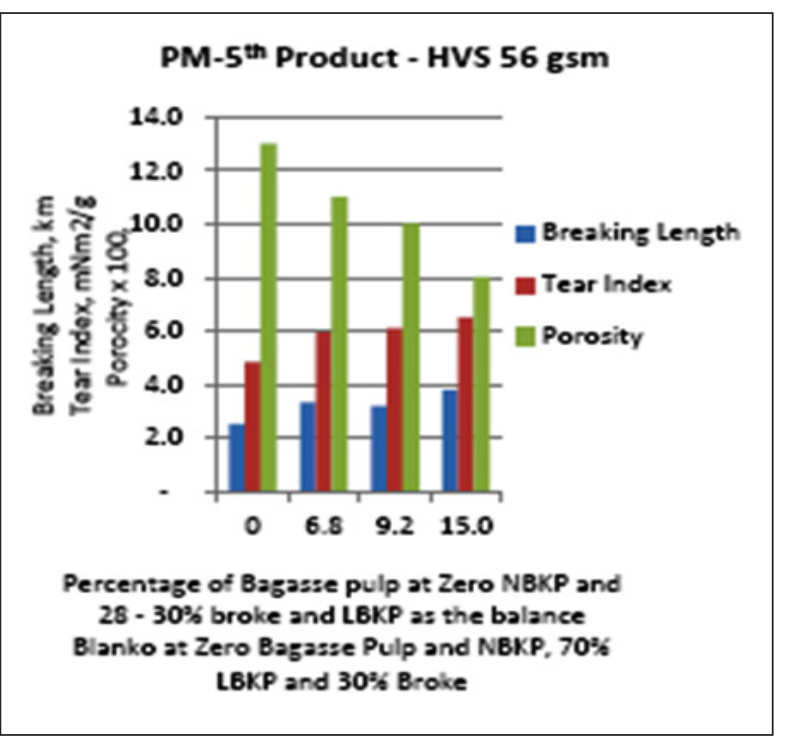

Figure 4. Effect of Bagasse Pulp on HVS 56 gsm
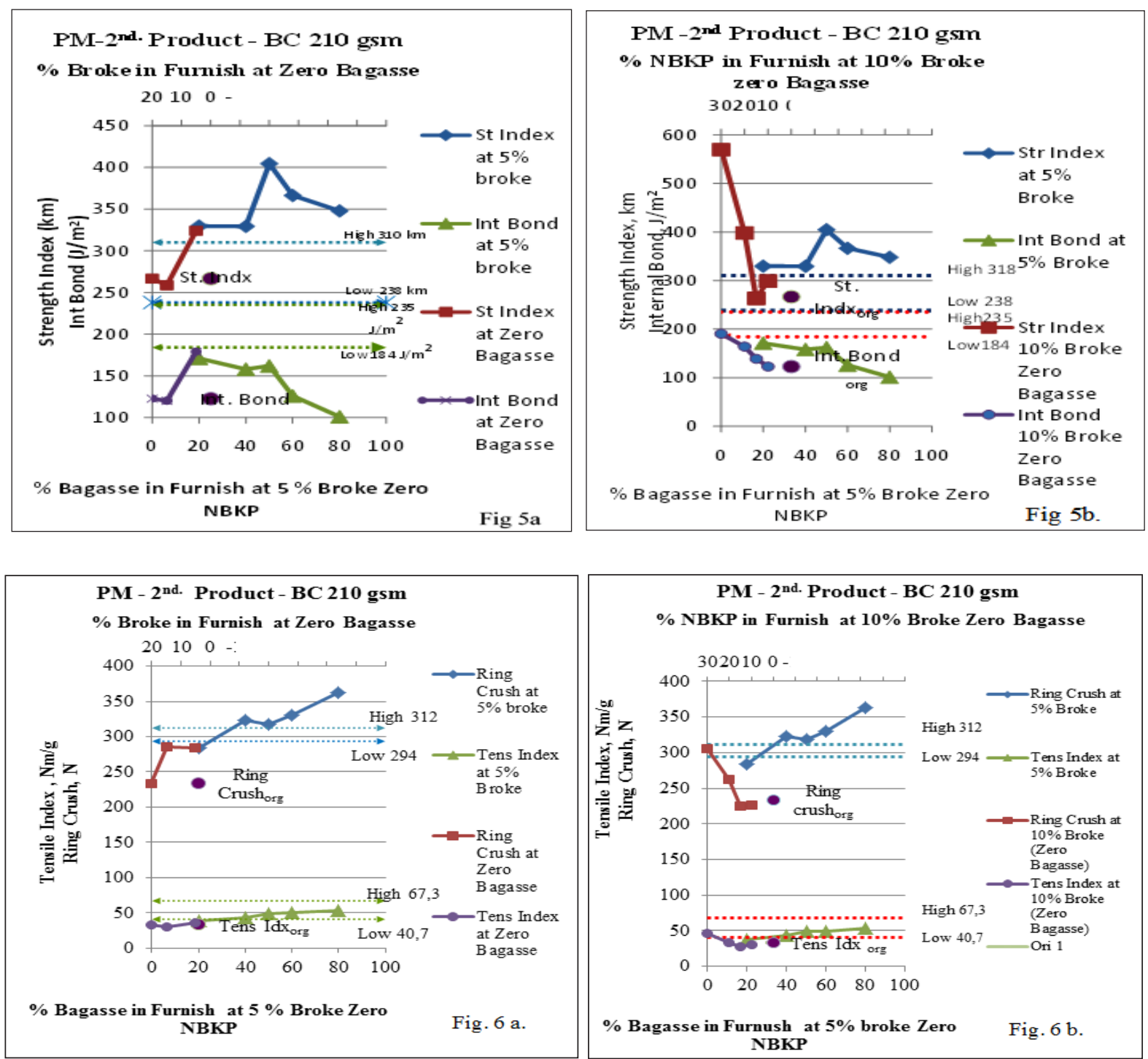

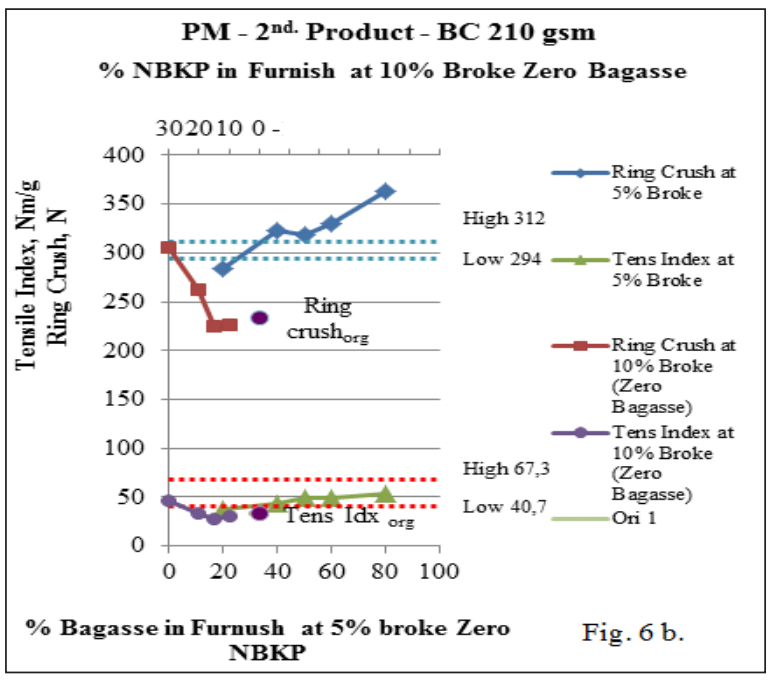

Figure 5a - 6a. Effect of Bagasse Pulp Substitute for LBKP on The Properties of BC 210 gsm and Figure 5b- 6b. Effect of Bagasse Pulp Substitute for NBKP on The Properties of BC 210 gsm. 

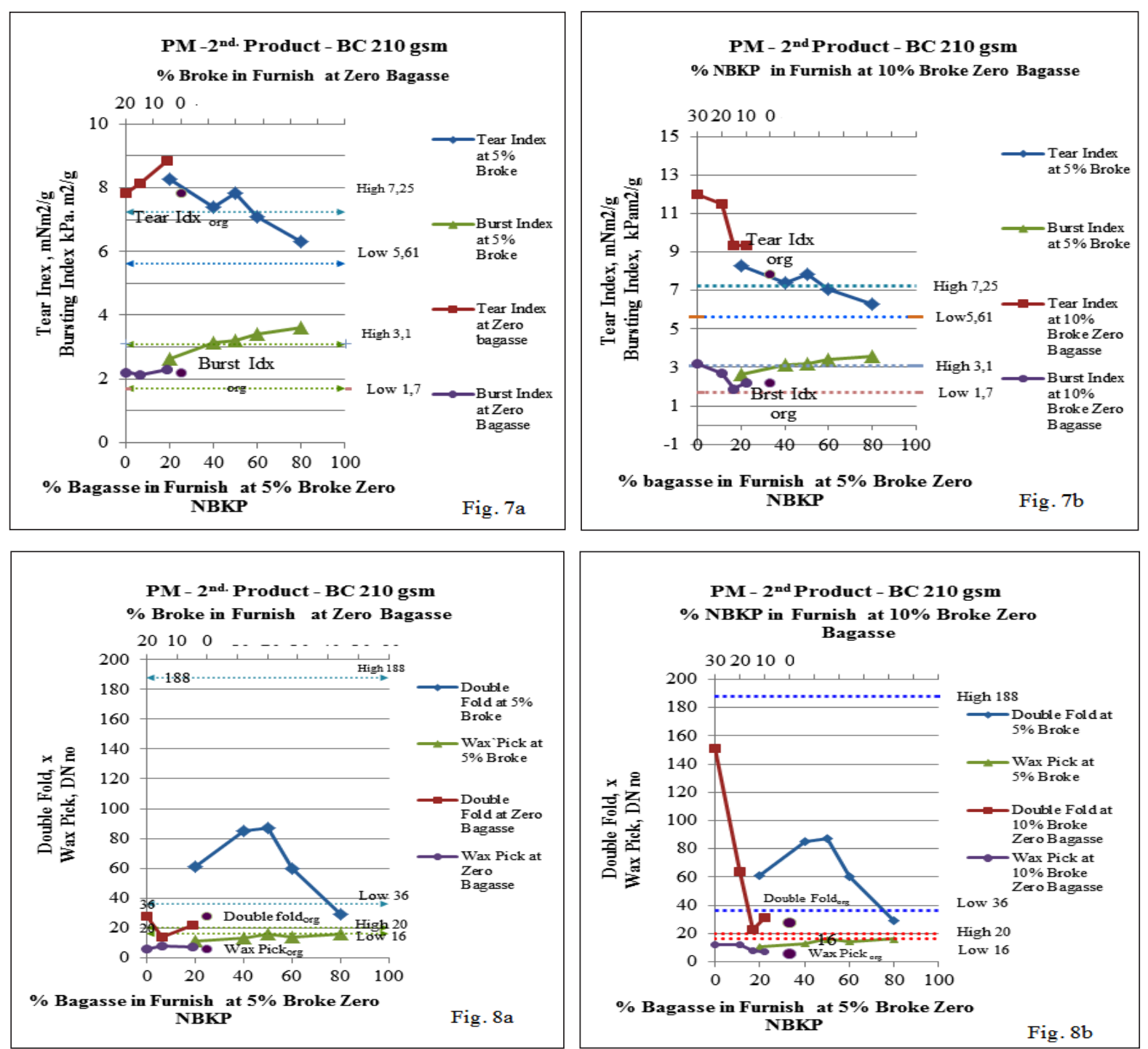

Figure 7a - 8a. Effect of Bagasse Pulp Substitute for LBKP on The Properties of BC 210 gsm and Figure 7b- 8b. Effect of Bagasse Pulp Substitute for NBKP on The Properties of BC $210 \mathrm{gsm}$

pulp substitute for $\mathrm{LBKP}$ on the properties of $\mathrm{BC}$ 210 gsm and Figure 5b- 6b. Effect of bagasse pulp substitute for NBKP on the properties of BC 210 gsm. Figure 7a - 8a. Effect of bagasse pulp substitute for LBKP on the properties of BC 210 gsm and Figure $7 \mathrm{~b}-8 \mathrm{~b}$. Effect of bagasse pulp substitute for NBKP on the properties of BC 210 gsm. From figure $5 \mathrm{a}, 5 \mathrm{~b}$ up to figure $8 \mathrm{a}, 8 \mathrm{~b}$, it can be concluded that bagasse pulp might substitute some portion of LBKP and even for NBKP to reach certain properties of paper. The first trial of the examined composition was the variation of bagasse pulp $20 \%, 40 \%, 50 \%, 60 \%$, and $80 \%$; recovered fibre $5 \%$; zero NBKP, and LBKP $15 \%$, $35 \%, 45 \%, 55 \%$, and $75 \%$ as the balance to reach $100 \%$ furnish composition. The second trial of the examined composition was Zero Bagasse, recovered fibre $10 \%$, NBKP $10,15,20,30 \%$; and
LBKP $60,70,75$, and $80 \%$ as a balance to reach $100 \%$ furnish composition

Examining and comparing figure $5 \mathrm{a}$ and $5 \mathrm{~b}$, $6 \mathrm{a}$ and $8 \mathrm{~b}, 7 \mathrm{a}$ and $7 \mathrm{~b}$, and so did for figure $8 \mathrm{a}$ and $8 \mathrm{~b}$. It is clear that bagasse pulp able to substitute a certain portion of LBKP (up to 50\%) and NBKP (up to $20 \%$ ) to get the accepted properties of strength index and internal bond (higher than the high standard of strength index on the market and a little bit lower than the low standard in case of internal bond even not so much decreased was happened) such as presented on figure $5 \mathrm{a}$ and $5 \mathrm{~b}$.

In case of ring crush and tensile index, bagasse pulp able to substitute LBKP portion up to $80 \%$ with higher ring crush and tensile index were resulted. It is also able to substitute NBKP portion up to $30 \%$ with the resulted ring crush and tensile index is far higher (figure 6a and 6b). Presented 
on figure $7 \mathrm{a}$ and $7 \mathrm{~b}$, substitution up to $50 \%$ LBKP with bagasse pulp kept the tear index above the high standard of tear index on the market but the bursting index incline higher even the substitution reach $80 \%$. Substitution up to $30 \%$ of LBKP with NBKP the resulted tear index is far higher but this is not compulsory because the tear index is much far higher than the necessary high standard of tear index on the market. In case of bursting index, using bagasse pulp is far better than NBKP. The same result was examined in case of double fold and wax pick test.

\section{CONCLUSION}

1. The use of bagasse pulp as the furnish constituent for MG tissue paper 17 gsm produced on $\mathrm{PM} 4^{\text {th }}$. able to substitute the whole LBKP portion ( $\pm 60 \%$ ), apparently has no negative effect on the physical properties of MG tissue $17 \mathrm{gsm}$ product.

2. The recommended composition for MG tissue $17 \mathrm{gsm}$ is $60 \%$ bagasse pulp, $35 \% \mathrm{NBKP}$ and $5 \%$ recovered fiber.

3. The use of bagasse pulp up to $15 \%$ to substitute LBKP in the furnish constituent for HVS 56 gsm produced on PM $5^{\text {th }}$ at $4,3 \%$ lower speed and $1 \%$ higher throughput able to improve strength index, tensile index, and tear index several point, and reduces the porosity reach $800 \mathrm{ml} /$ minute.

4. The recommended composition for base paper HVS 56 gsm is $15 \%$ bagassse pulp, $30 \%$ recovered fiber, and $65 \%$ LBKP.

5. The use of bagasse pulp as the furnish constituent for BC paper $210 \mathrm{gsm}$ that produced on PM $2^{\text {nd }}$ at the same speed and throughput able to substitute some portion of LBKP $(40 \%-$ $80 \%)$ and NBKP $(10 \%-20 \%)$ with apparently no negative effect on its physical properties. In case of strength index and internal bond, bagasse pulp able to substitute certain portion of LBKP (up to 50\%) and NBKP (up to $20 \%$ ) to get the accepted properties of strength index and internal bond. In case of ring crush and tensile index, bagasse pulp able to substitute LBKP portion up to $80 \%$ with higher ring crush and tensile index were resulted. It is also able to substitute NBKP portion up to $30 \%$ with the resulted ring crush and tensile index is far higher.
6. Properties of BC $210 \mathrm{gsm}$ of PM $2^{\text {nd }}$ still on between the high and low level properties of $\mathrm{BC}$ 210 gsm available on the market, even though a sharp decrease of strength index, tear index and double fold has been found when compared to BC 210 gsm use 20\% - 30\% NBKP.

7. The recommended composition for BC 210 gsm is $50 \%$ bagasse pulp, 45\% LBKP and recovered fiber $5 \%$ maximum.

8. The use of NBKP is not necessary in case bagasse pulp is used as the main constituent, but NBKP will be recommended for maximum $20 \%$ in case on the absent of bagasse pulp in the composition.

\section{REFERENCES}

Anonym, Innovation of Bagasse in Pulp \& Paper Industry, Pulp and paper - Technology.com, Ochre Media All Rights Reserved, 2001-2013.

Emily Matthews, Charles Barber, Restu Achmaliadi, Togu Manurung, et. al. The State of the Forest: Indonesia, WRI, 2002.

Fenta, D. T., The Economic significance of using bagasse as a resource of raw material for pulp manufacturing - A case study, Research report of University of South Africa, 2010.

FWI/GFW, 2002, The State of the Forest: Bogor, Indonesia: Forest Watch Indonesia, and Washington DC: Global Forest Watch.

Hurter, P and Robert W, 2001, Non wood Plant fiber uses in Papermaking, Non Wood Fiber Short Course Notes, 2001.

Kasmani J. E., et all. Studying the Effect of the Age in Eucalyptus camaldulensis Species on Wood Chemical Compounds Used in Pulping Process., American-Eurasian J. Agric. \& Environ. Sci., 11 (6): 854-856, 2011.

Kocurek, M. J., Hamilton, F., and Leopold, B., 1993, Secondary Fiber and Non-Wood Pulping - Pulp and Paper Manufacture, Vol. 3, TAPPI.

Otto Miettinnen and Harri Lammi, A Study on the Finnish involvement in Industrial Pulp Plantations in Indonesia: Riau Andalan Pulp and Paper (Sumatra) and Finnantara Intiga (Borneo). Friends of the Earth-Finland in consultation with WALHI/ Friends of the Earth-Indonesia,WRM, 2002

Poyry Consulting, Report of Market analysis DFID, 2012. 